\title{
Much in Little: The Umbrella Clause that Changes the International Investment Protection Standard
}

\author{
Kartika Paramita \\ International Business Law Program, Universitas Prasetiya Mulya, Indonesia. \\ E-mail: kartika.paramita@pmbs.ac.id
}

\begin{tabular}{l} 
ARTICLE INFO \\
\hline Keywords: \\
Bilateral Investment \\
Treaty; ICSID; \\
Investment; \\
Umbrella Clause \\
How to cite: \\
Paramita, K. (2020). Much \\
in Little: The Umbrella \\
Clause that Changes the \\
International Investment \\
Protection Standard. \\
Hasanuddin Law Review, \\
6 (1): 25-45 \\
DOI: \\
10.20956/halrev.v6i1.1570
\end{tabular}

\begin{abstract}
The umbrella clause of a Bilateral Investment Treaty (BIT) establishes an obligation for the State parties to respect all commitments entered into by an investment contract between an investor and the host country. It extends the jurisdiction of a BIT forum to the breach-of-contracts matters and changes the nature of a private issue to an international affair. The polemic over the clause's interpretation has become a controversial issue over the years. It comes as a backlash for the Contracting States as a foreign investor could quickly bring an investment problem to an international forum. After more than a decade since its first discussion in the case of SGS $v$ Pakistan, the clause grows to be one of the reasons for many countries to leave or reform their BIT model and changes the trend of international investment protection standard. This article addresses the different episodes of the umbrella clause alongside over the past decade. It projects the debate over the clause's scope, its development, the governments' action, and their perception over it, and finally, how it changes the standard of investment protection in international treaties.
\end{abstract}

\section{Introduction}

In 2003, Société Générale de Surveillance S.A (SGS) a company headquartered in Geneva filed a claim against the Islamic Republic of Pakistan before the arbitration tribunal of International Centre for Settlement of Investment Disputes (ICSID). The claim was based on a violation of an agreement made between both of the parties, which SGS claimed had elevated to a breach of bilateral investment protection 
agreement (BIT) formed between the Swiss Confederation and Pakistan in 1995. ${ }^{1}$ The treaty document had chosen ICSID to settle its future investment dispute. Pakistan, however, objected to its jurisdiction. It asked the Tribunal to decline the case since a more specific arbitration tribunal under the law of Pakistan had already been established based on the agreement made between the parties. ${ }^{2}$

SGS's claim on the "elevation" was based on Article 11 of the BIT that says, "either Contracting Party shall constantly guarantee the observance of the commitments it has entered into with respect to the investments of the investors of the other Contracting Party." Considering the agreement was one of the investment commitments made by Pakistan, SGS thus submitted an inquiry upon its violation to the forum of the BIT. Later, such similar clause is known as the umbrella clause.

The umbrella clause is often interpreted as a blanket clause that gives protection for foreign investment. ${ }^{3}$ The clause is so named because it provides umbrella protection of international law for contractual commitments entered by the host state. ${ }^{4}$ The clause grants additional protections beyond the guarantees of a treaty. When an umbrella clause is in effect, a violation of an investment contract conducted by a State can be escalated to a breach of international law.

SGS v. Pakistan was the first modern arbitral tribunal dealing with the issue of umbrella clause. The tribunal, in its decision, chose to follow a narrow interpretation and asserted that it was not the purpose of Article 11 to be interpreted in such manner. The BIT was made after the conclusion of the agreement and without any indication of an acceptance of a new international law obligation. ${ }^{5}$ Furthermore, the umbrella clause was not placed together on the substantive part of the treaty. Accordingly, the clause shall not be interpreted expansively. ${ }^{6}$ However, just five months after such decision, the ICSID tribunal released another award on SGS v. Philippines. The decision was in nature contradicts with the previous judgment, although they were using a very similar umbrella clause. ${ }^{7}$ According to the tribunal, the clause's objective is to give an assurance to the investor that the Host State will perform its obligation. Consequently, the clause shall not be interpreted in a restrictive way. ${ }^{8}$ Since then, those two cases become the beginning of a lengthy debate over the clause's interpretation.

1 The Agreement between the Swiss Confederation and the Islamic Republic of Pakistan on the Promotion and Reciprocal Protection of Investments, 11 July 1995.

2 Pre-Shipment Agreement (PSI Agreement) between SGS and the Islamic Republic of Pakistan, 29 September 1994.

3 Subedi, S. P. (2008). International Investment Law Reconciling Policy Principle. Oxford and Portland, Oregon: Hart Publishing, 104.

4 Ibid.

5 SGS Société Générale de Surveillance S.A. v. Islamic Republic of Pakistan. ICSID Case No. ARB/01/13 Decision of the Tribunal on Objections to Jurisdiction (2003). Retrieved from https://www.italaw.com/cases/1009, 167.

6 Ibid., 169, 170, 171.

7 SGS Société Générale de Surveillance S.A. v. Republic of the Philippines. ICSID Case No. ARB/02/6 Decision of the Tribunal on Objections to Jurisdiction. Retrieved from https://www.italaw.com/sites/default/files/case-documents/ita0782.pdf, 113-129.

8 Alexandrov, S. A. (2004). Breaches of Contract and Breaches of Treaty - The Jurisdiction of Treatybased Arbitration Tribunals to Decide Breach of Contract Claims in SGS v. Pakistan and SGS v. Philippines. Journal of World Investment and Trade, 4(5), 125. 
More than a decade after its first discussion, no less than 14 arbitration cases ${ }^{9}$ and hundreds of works of literature had been addressing the issues of the clause. Yet, no consensus has been achieved among the arbitrators, and different approaches have been taken to make judgments. The application of the clause has risen issues on how the tribunal should see the real intention of the BIT member states, such as: whether it is genuinely their objectives to make such elevation effect; or whether the clause has a power to supersede the forum of the investment agreement; or who can enjoy the benefit of the clause, whether it has an effect to a parent company when it was its subsidiary that signed the investment agreement, or whether the clause covers the substate entities that signed an investment agreement with a private company.

Those issues on the umbrella clause have changed how the States perceive their investment agreements and make a new position with their international investment policies. Fifteen years ago, it was estimated that $40 \%$ of all BITs in the world contained an umbrella clause. ${ }^{10}$ Currently, this number has been dropped to only $3.7 \%$ of the available instruments of investment protection in the world contain an umbrella clause. ${ }^{11}$ States start to revisit their investment treaties and add more clarifications on the clause along with the increasing number of investment arbitration claims. Further, as the clause has shown a substantial practice on how a private matter within a State can directly affect international law and vice versa, the standard of international investment protection has subsequently changed as a response to such development.

This article aims to deliver one summary of lengthy episodes of umbrella clause discussion as well as give a basic understanding of how the clause changes the trend of investment protection in countries. The next section of this paper explores the origins of the investment protection standard and the umbrella clause's history. It will be followed by an analysis of how the precedent cases perceive the clause, in which situation a breach of a contract can be interpreted as a breach of an umbrella clause and who can enjoy the benefit of the clause. Lastly, it will address the current trend on how States modify their investment policies for foreign investors and how the global protection standard has then changed.

\section{The Origins of the Investment Protection Standard, the BITs and the Umbrella Clause}

\subsection{Early Development of the Investment Protection Standard}

Before the colonial era and during the peregrination of the Europeans, it was understood that each nationality was subject to his home state's law. ${ }^{12}$ The relation

9 Cases addressing the debate on umbrella clause, among other things: SGS v. Pakistan, Toto Construzioni v. Lebanon, Salini v. Jordan, El Paso v. Argentina, Siemens v. Argentina, Joy Mining v. Egypt, SGS v. Philippines, BIVAC v. Paraguay, Bosh v. Ukraine, SGS v. Paraguay, Eureko v. Poland, Noble Ventures v. Romania, Burlington v. Ecuador, Duke Energy v. Ecuador.

10 Gill, J., Gearing, M., \& Bert, G. (2004). Contractual Claims and Bilateral Investment Treaties, A Comparative Review of the SGS Cases. Journal of International Arbitration, 21(5), 397-412.

11 De Souza Fleury, R. P. (2017). Closing the umbrella: A Dark Future for Umbrella Clause? Retrieved January 31, 2020, from http://arbitrationblog.kluwerarbitration.com/2017/10/13/closing-umbrella-dark-futureumbrella-clauses/.

12 Article 4 of the Sheikhdom of Bahrain and the British Government Treaty in 1861 specifically mentioned, "All offenses which they may commit or which may be committed against them, shall be reserved for the decision of the British Resident, provided the British agent of Bahrain shall fail to adjust them satisfactorily." At that time, many treaties concluded between European with Asian or African maintained the jurisdiction of the Europeans' home states. See: Sutton, S. D. (2005). Emilio 
among nations was built based on a solid friendship, which was reflected in the rules of international law. The alien properties were protected, and States could not invoke national laws to expropriate other nations' assets.13 When the colonial era began, investment was rather seen to expand the colonial area and safeguarded by the imperial system and lobbying. ${ }^{14}$ As a result, the investment did not need to be protected as it became a part of the colonial system, and the order was believed had given sufficient protection for the investment. 15

It was until 1868, an Argentine jurist, Carlos Calvo, for the first time, introduced another perspective on how nations should see the foreign investments. At that time, Calvo was criticizing how foreigners were entitled to get more benefits than the nationals of the country they reside in. ${ }^{16} \mathrm{He}$ then emphasized the absolute equality between the foreigners and the nationals and how the local remedies within a country should be prioritized, implying a rejection of the non-local remedies and laws, including the diplomatic protection or military intervention or the international laws as the applicable laws. ${ }^{17}$ Calvo saw that it was the responsibility of the government to create an environment in which the foreigners' advantages could not be more significant than that which the government had towards its citizens. ${ }^{18}$ His national treatment doctrine was firmly rejected by the European and the US governments but eagerly received by the newly independent Latin American governments, which started to put the theory into their investment documents. ${ }^{19}$ Most of them were relying on the doctrine of state sovereignty and equality to uphold Calvo's principle. ${ }^{20}$

Responding to the development of Calvo's national treatment doctrine, in 1910, an American lawyer Elihu Root came up with an argument that there is a minimum standard of justice under international law. Even though States can treat foreigners with the same treatment they give to their nationals, it does not evade their obligations under international law. ${ }^{21}$ Hence, the local law shall be made in line with the international justice standard, and in case the local law is not well developed, the international law shall apply to such matters. Breach of such minimum standard will bring responsibility to the host State and gives a legitimate basis by the investor-State to offer protection to its nationals. ${ }^{22}$ This concept completes the national treatment

Augustin Maffezini v. Kingdom of Spain and the ICSID Secretary-General's Screening Power. Arbitration International, 21(1), 113-126. Retrieved from $h$ ttps://doi.org/10.1093/arbitration/21.1.113, 119.

13 Cited in Moore, J. B. (1906). A Digest of International Law (Vol 4). Washington: Government Printing Office: John Adam stated: "There is no principle of the law of nations more firmly established than that which entitles the property of strangers within the jurisdiction of another country in friendship with their own to protection of its sovereign by all efforts in his power."

14 Sornarajah, M. (2010). The International Law on Foreign Investment (Third Edition). New York: Cambridge University Press, 19.

15 Ibid.

16 Shea, D. R. (1955). The Calvo Clause: A Problem of Inter-American International Law and Diplomacy. University of Minnesota Press. Retrieved from https://www.jstor.org/stable/10.5749/j.ctttt1ms, 18 based on Calvo's book titled Le Droit International (1885).

17 Shan, W. (2007). Is Calvo Dead? The American Journal of Comparative Law, 55(1), 123-163, 126.

18 Sornarajah, M., op. cit., 19.

19 Shan, W., op. cit.. 127.

20 Subedi, S. P., op. cit., 8.

21 Root, E. (1910). The Basis of Protection to Citizens Residing Abroad. In American Society of International Law at Its Annual Meeting (1907-1917) (pp. 16-27). Cambridge University Press. Retrieved from $h t t p s: / / w w w . j s t o r . o r g / s t a b l e / 25656384$.

22 Asante, S. K. B. (1988). International Law and Foreign Investment: A Reappraisal. The International and Comparative Law Quarterly, 37(3), 588-628. Retrieved from https://www.jstor.org/stable/760279. 
doctrine in the sense that it will give additional protection for foreign investors under international law in case the national law does not provide enough security.

It can be seen so far that the development of investment protection concept was based on the argument between the investor countries (which most of them was the wellestablished nations through the international law) and the host states (which most of them was the newly independent states through their national legislation). Regardless of the debate, the idea of a government could take foreigners' properties for economic reform did not start to appear until the Russian revolution in 1917. The Soviet Union government at that time expropriated the foreign properties without compensation based on the economic philosophy, the standard of national treatment, and for the sake of sovereignty. The Western states vehemently opposed this action. The USSR reform later initiated a similar revolution in Mexico. In 1938, Mexico was conducting an expropriation towards the US interests in the Mexican oil business. Responding to such matters, the US Secretary of State, Cordell Hull, sent a letter to Mexico reiterated his position that the US recognized the right of Mexico to conduct such expropriation for the public purpose. However, he asserted that under international law, an expropriation had to be conditioned on the obligation to make adequate, effective, and prompt compensation. ${ }^{23}$ This requirement is later known as the Hull formula. The Mexican government, nevertheless, maintained its position that a state has a sovereign right to expropriate the foreign properties and to determine the compensation based on the stipulation of the national laws of Mexico.

After the Second World War, the discussion regarding the suitable international law instruments that govern foreign investment started to come to the surface. The newly independent mineral-rich countries came up with the principle of permanent sovereignty over natural resources as the manifestation of their self-determination. ${ }^{24}$. In 1962, such effort eventually yielded a positive result. The United Nations General Assembly (UNGA) adopted a resolution 1803 regarding the Declaration on Permanent Sovereignty over Natural Resources. The document emphasized equal sovereignty of the States to manage their natural resources as well as balancing the Calvo's national standard doctrine and the minimum standard supported by the western countries. Through the resolution, States agreed that among other things: 1) nationalization or expropriation is possible to be done only based on public utility, security or the national interest; 2 ) there is a possibility to bring investment dispute to an international dispute settlement forum; 3) foreign investment agreements shall be observed in good faith, and the states and international organization should respect the principle of Permanent Sovereignty over Natural Resources. The document later initiates the establishment of the United Nations Conference on Trade and Development (UNCTAD).

The 1970s become the era where many developing countries began an intense confrontation against the investor states. Started with the nationalization of most of the equity-based concession arrangements by the oil-producing countries, it went stronger

23 Dolzer, R., \& Schreuer, C. (2012). Principles of International Investment Law (Second). Oxford University Press, 2. See also: Hackworth, G. H. (1942). Digest of International Law (Vol 3). Washington: United States Government Printing Office.

24 Such control could entail the right to explore, exploit, and dispose of the countries' natural resources as well as the right to regulate foreign investment and settle a dispute based on national law. See: Ng'ambi, S. P. (2015). Permanent Sovereignty Over Natural Resources and the Sanctity of Contracts, From the Angle of Lucrum Cessans. Loyola University Chicago International Law Review, 12(2), 153172. Retrieved from $h t t p s: / /$ awecommons.luc.edu/cgi/viewcontent.cgi? article=1176Econtext=lucilr. 
with the issuance of several UNGA resolutions on the so-called "New International Economic Order." The resolutions gave States the right to nationalize their natural resources or economic activities based on full permanent sovereignty of each state within its national jurisdiction in accordance with its domestic law and regulations. ${ }^{25} \mathrm{It}$ made the expropriation became a common issue ${ }^{26}$ mainly when the new independent socialist and communist countries such as the USSR, the People's Republic of China, and Cuba started to nationalized foreign properties. This situation, however, lasted only until the early 1980s as economic independence had brought financial crisis and economic stagnation rather than prosperity to the developing countries, particularly those in Latin America and Africa. ${ }^{27}$ The number of expropriations was then rapidly declining in the following years. ${ }^{28}$

In 1989, J. Williamson, an English economist, coined the term of Washington Consensus in a conference paper convened by the Institute for International Economics. The term refers to ten policy actions that suggested that economic liberalism was rather desirable to make structural reform in all Latin American countries rather than protective effort. ${ }^{29}$ These actions made a strong impression among nations, including major financial institutions such as the IMF, World Bank, and the U.S. Treasury. It then marked the beginning of the new international investment law trend. The investment host States started to conclude international investment treaties not only with the capital-exporting States but also among themselves rather than relying on the customary international law as in the previous practice. They granted more protection to attract foreign investors, including employing the Hull formula as an expropriation standard in those treaties. ${ }^{30}$ From that moment onwards, the investment protection standard is mostly determined based on the agreement among the States themselves.

\subsection{The Raise of Umbrella Clauses and the Emergence of the BITs}

The concept of umbrella clause was initially introduced by Elihu Lauterpacht, an English scholar and lawyer during the settlement of Anglo-Iranian Oil Company (AIOC, subsequent British Petroleum) nationalization by the Iranian government in

25 United Nations General Assembly Resolution 14 December. (1962). Permanent Sovereignty over Natural Resources (No. 1803 (XVII)).

26 Lipson, C. (1985). Standing Guard, Protecting Foreign Capital in the Nineteenth and Twentieth Centuries. London: University of California Press.

27 Dolzer, R., \& Schreuer, C., op. Cit. 5.

28 Guzman, A. T. (1998). Why LDCs Sign Treaties That Hurt Them: Explaining the Popularity of Bilateral Investment Treaties. Virginia Journal of International Law, 38, 639-688.

29 The original Washington Consensus: 1) Budget deficits...should be small enough to be financed without recourse to the inflation tax; (2) Public expenditure should be redirected from politically sensitive areas that receive more resources than their economic return can justify...toward neglected fields with high economic returns and the potential to improve income distribution, such as primary education and health, and infrastructure; (3) Tax reform... so as to broaden the tax base and cut marginal tax rates; (4) Financial liberalization, involving an ultimate objective of market-determined interest rates; (5) A unified exchange rate at a level sufficiently competitive to induce a rapid growth in non-traditional exports; (6) Quantitative trade restrictions to be rapidly replaced by tariffs, which would be progressively reduced until a uniform low rate in the range of 10 to 20 percent was achieved; (7) Abolition of barriers impeding the entry of foreign direct investment; (8) Privatization of state enterprises; (9) Abolition of regulations that impede the entry of new firms or restrict competition; (10) The provision of secure property rights, especially to the informal sector. See: Williamson, J. (2004). The Strange History of the Washington Consensus. Journal of Post Keynesian Economics, 27(2), 195-206. Retrieved January 15, 2020, from www.jstor.org/stable/4538920.

30 Dolzer, R., \& Schreuer, C., op. Cit. 5. 
late 1953. It was Lauterpacht's idea to incorporate a settlement in a treaty that was automatically governed by the international law ${ }^{31}$ or to arrange a condition when there is a breach of the contract or a settlement, it shall be ipso facto deemed to be a breach of the treaty. ${ }^{32}$

In order to create such condition, he suggested the company make a Consortium Agreement between the company and the Iranian government, which incorporated an umbrella treaty by annex and contained an obligation for the Iranian government to fulfill all its terms to safeguard the nationalization process. ${ }^{33}$ The making of such umbrella treaty basically had two objectives. First, it ensured that the settlement of the dispute would not be regulated exclusively by Iranian law. Second, it was purposed to give a choice for the company to settle the dispute, whether it was under the Consortium Agreement's forum or to elevate the dispute as a breach of the Government's obligation under the jurisdiction of the International Court of Justice. In the end, Lauterpacht's concept of the umbrella treaty was never materialized. However, the idea and the notion of protecting the investor interest under an international obligation started to be known.

In 1957, Hermann Abs, the Chairman of Deutsche Bank, came up with a draft of the International Convention for the Mutual Protection of Private Property Rights in Foreign Countries. Through the draft, Abs suggested to the investor states to make a unified 'system of joint measures' to protect private properties or other private rights. ${ }^{34}$ The document was called the 'Magna Charta of the investments' 35 and contained specific investment standards for the host states, including the idea of the establishment of a permanent arbitral tribunal to safeguard the application of the investment convention and give an economic sanction against the violating states. ${ }^{36}$

Abs eventually met Shawcross in 1958, a former British Attorney General who previously had been working on the draft of Convention on Foreign Investment. The Shawcross draft endorsed the adherence to the rules of international law to strengthen the binding force of an investment contract. ${ }^{37}$ One year later, they published the combination of both conventions, the so-called draft Convention on Investment Abroad, as an effort to set a code for foreign investment. The Abs-Shawcross draft was the first multinational convention that covered the umbrella clause. ${ }^{38}$ It even gave wider umbrella stipulation, which covered any undertakings related to the investment made by nationals of any other state party rather than the previous Lauterpacht's that

31 Sinclair, A. C. (2004). The Origins of the Umbrella Clause in the International Law of Investment Protection. Arbitration International, 20(4), 411-434, 415, citing Lauterpacht, E. (1953). Anglo-Iranian Oil Company Ltd Persian Settlement - Note dated 7 December 1953.

32 Sinclair, A. C., op.cit. Citing Lauterpacht, E. (1954b). Anglo Iranian Oil Company Ltd Persian Settlement - Opinion dated 20 January 1954. 4.

33 Sinclair, A. C., op.cit. Citing Lauterpacht, E. (1954a). Anglo-Iranian Oil Company Ltd Persian Settlement - Note dated 12 March 1954. 18.

34 Sinclair, A. C., op.cit. Citing Abs, H. J. (1958). Proposals for Improving the Protection of Private Foreign Investments. Rotterdam: Investments (Institut International d'Etudes Bancaires).33.

35 Sinclair, A. C. op.cit. Citing Abs, H. J. (1957). The Safety of Capital. San Francisco: San Francisco International Industrial Development Conference in October 1957.

36 Dolzer, R., \& Schreuer, C., op. Cit. 8.

37 The draft was made to remedy the UK's failure in the AIOC case. According to the draft, the umbrella clause shall be applicable not only to a particular investment agreement but to specific engagements to the investor. See: Anglo-Iranian Oil Co. Case (the United Kingdom v. Iran). Jurisdiction, ICJ Report Judgment of July 22nd (1952), 93.

38 Sinclair, A. C. op.cit 422. 
only covered a specific treaty. ${ }^{39}$ This kind of stipulation is later known as the umbrella clause.

The Abs-Shawcross draft continued to influence the development of the investment treaty. It later initiated the establishment of the Organization for Economic Cooperation and Development (OECD) and the organization's Draft Convention on the Protection of Foreign Property in 1967.40 One of the substantive rules stipulated on the Article 2 of such document was the 'Observance of Undertakings,' which provided: "Each party shall at all times ensure the observance of undertakings given by it in relation to property of nationals of any other Party." The document commentary emphasized how such article covered an expansive area of interpretation ${ }^{41}$ Although this effort to make a multilateral treaty for foreign investment was not accepted by many developing states as it was energetically favorable to the capital-exporting states, the draft was used as a model for the conclusion of BIT among its member states. ${ }^{42}$

At the same time, with such development, Germany and Pakistan signed the very first Bilateral Investment Treaty (BIT) in 1959, which also contains an umbrella clause. ${ }^{43}$ There are several reasons why nations prefer to use the form of bilateral treaties rather than multilateral. Foreign investment is rather a sensitive issue, particularly to the developing states since it is directly related to the problems of sovereignty, domestic policies as well as the right to exploit states' natural resources. ${ }^{44}$ Hence, the States tend to be very cautious in choosing the right investment partners. The form of a bilateral treaty is also somewhat flexible to be adjusted with the interest of each state in which the multilateral treaties are lack of. Moreover, BIT provides a more apparent guarantee for the investment, 45 which also supports the customary international law on investment protection standards. 46

In the late 1980s, the number of BITs concluded increase significantly among the developing states. This phenomenon happened due to the lack of source of capital, the need for technology development as well as the debt crisis that limited their access to private lending. ${ }^{47}$ The resistance of several Asian countries in facing economic difficulties due to their openness to private investment and effort to produce export goods eventually had inspired many states to switch their policies to a more foreign

39 The term will include not only the written obligations but also other forms of commitments entered by each State Party. See: Abs, H., \& Shawcross, A. (1960). The Proposed Convention to Protect Private Foreign Investment. Journal of Public Law, 9, 115.

40 OECD. Draft Convention on the Protection of Foreign Property 12 October (1967). Retrieved from https://www.oecd.org/daf/inv/internationalinvestmentagreements/39286571.pdf.

41 Including among others the meaning of 'property' and 'undertakings.' See: Ibid. The Notes and Comments to Article 2, paragraph 2, and paragraph 3(a).

42 1983, 1984, and 1987 US Model BIT; French Model BIT; UK investment protection treaty-making; Dolzer, R., Stevens, M., \& ICSID. (1995). Bilateral Investment Treaties. The Hague: Martinus Nijhoff Publishers. 2.

43 "Either Party shall observe any other obligation it may have entered into concerning investment by nationals or companies of the other Party" Article 7 Treaty between the Federal Republic of Germany and Pakistan for the Promotion and Protection of Investments of 25 November 1959.

44 Sornarajah, M., op. Cit. 183.

45 Dolzer, R., \& Schreuer, C., op. Cit. 13.

46 Denza, E., \& Brooks, S. (1987). Investment Protection Treaties: United Kingdom Experience. The International and Comparative Law Quarterly, 36(4), 908-923. Retrieved from https://www.jstor.org/stable/760362. 912.

47 Agrawal, K. (2016). Bilateral investment treaties: a developing history. Jindal Global Law Review, 7, 175-199. https://doi.org/https://doi.org/10.1007/s41020-016-0031-x. 
investment-friendly. ${ }^{48}$ From 1959 to 1989, it was recorded that less than four hundred BITs concluded. This number improved dramatically to be at least two thousand BITs completed during the next fifteen years period of 1989 to $2004 .{ }^{49}$ Meanwhile, the umbrella clause continued to exist during such time as a part of the model of BIT and became more varies in its wording. ${ }^{50}$

Chart 1. The Development of the Investment Protection Standard and the Raise of Umbrella Clause

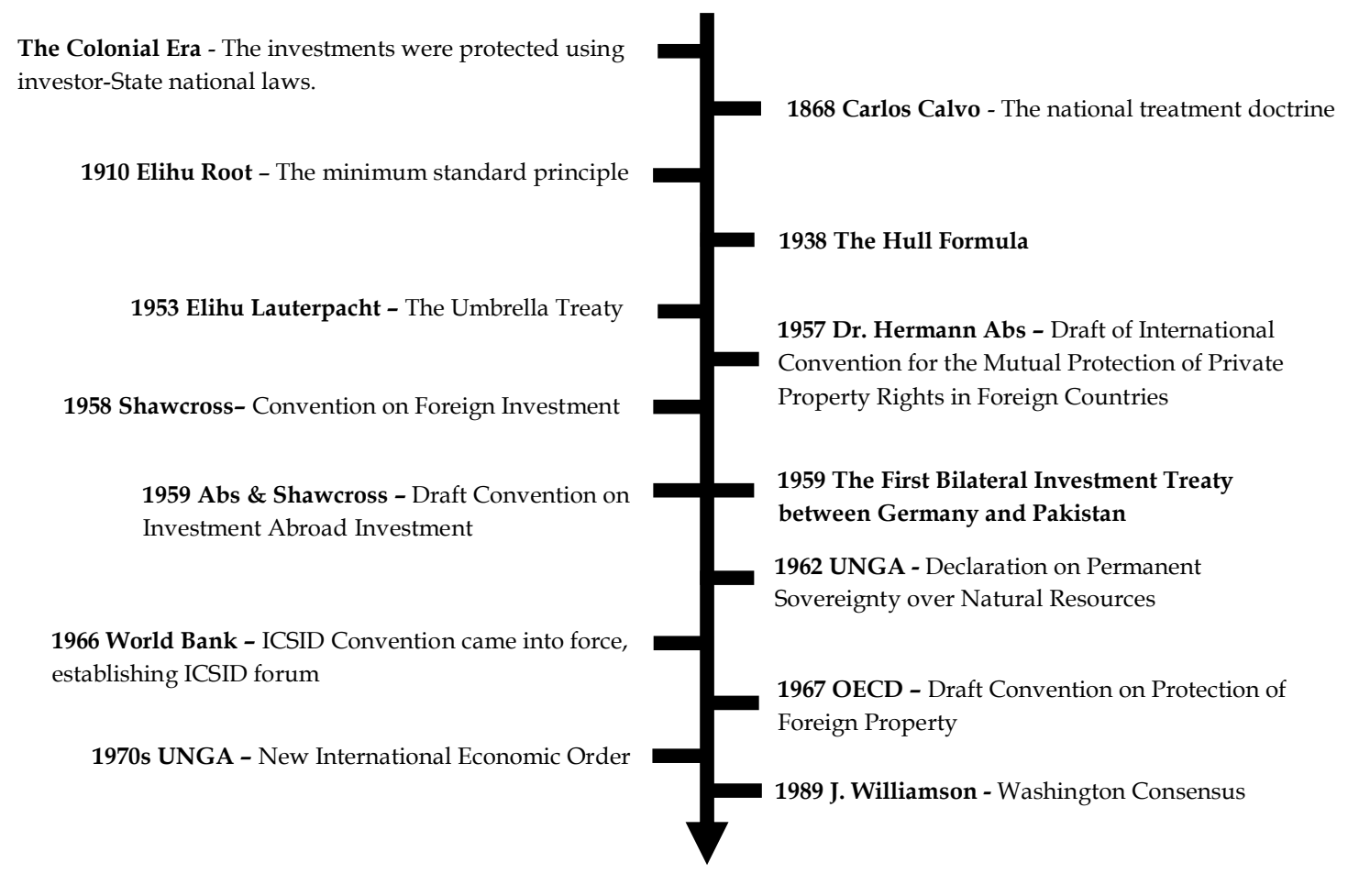

Source: Primary Data, 2018 (edited)

\section{The Umbrella Clause in Practice}

The umbrella clause is also known as the parallel protection, pacta sunt servanda, or the sanctity of contract. ${ }^{51}$ It is basically a catch-all provision that seeks to enforce all assurances and commitments made to the foreign investor by a host State. 52 Since the beginning of its concept, an umbrella clause is purposed to elevate a private agreement

48 Fernandez Jilberto, A. E., \& Mommen, A. (Eds.). (1996). Liberalization in the developing world: institutional and economic changes in Latin America, Africa, and Asia. London; New York: Routledge.

49 United Nations Conference on Trade and Development. (1998). Bilateral Investment Treaties in the Mid-1990s. New York: United Nations Publication, 8, 117.

50 For example, Article 10(1) of the Energy Charter Treaty gave an extensive umbrella clause coverage to the Contracting Party by stipulating," [The Contracting Parties] observe any obligation [...] entered into with an Investor or an Investment of an Investor of any other Contracting Party. Sometimes the umbrella clause could be short, included in the fair and equitable treatment part, as is the stipulation in the 1990 UK - Argentina BIT.

51 OECD. (2008). International Investment Law: Understanding Concepts and Tracking Innovations: A Companion Volume to International Investment Perspectives. Paris: OECD Publishing. https://doi.org/https://doi.org/10.1787/9789264042032-en. 102.

52 Sornarajah, M., op. cit., ft. 39. 
made between an investor with a host state to be an international obligation and to provide additional protection to a foreign investor.

Several years before the judgment of SGS $v$. Pakistan, the issue of the umbrella clause had arisen in another ICSID case, Fedax N.V.v. the Republic of Venezuela. The tribunal, in such case, was unaware of the existence of the umbrella clause and simply adopted the plain meaning of the provision that all commitments should be performed according to the BIT. The tribunal found Venezuela was obliged to "honour precisely the terms and conditions governing such investment, laid down mainly in Article 3 of the Agreement, as well as to honour the specific payments established in the promissory notes issued". 53

After the fundamental judgments on SGS v. Pakistan and SGS v. Philippines in 2003, the discussion regarding such clause started to rise, and the tribunals' decisions on the issue have continued to vary. Their interpretations toward the clause were mainly influenced by three factors, namely: the wording of the clause, the nature of the investment contract, and the appropriateness of the Contracting Parties. Several other aspects that they took into account in the judgment making are the placement of the clause, the specification of the commitments protected by the clause, and the party who can benefit the clause's protection. ${ }^{54}$

\subsection{The Interpretation of Umbrella Clause}

In general, there were two approaches used by the tribunals to interpret the wording of the umbrella clause within a BIT: (1) narrow-interpretation or (2) broad-interpretation. The narrow interpretation was firstly articulated by SGS v. Pakistan tribunal as it found that the nature of the umbrella phrase stated on Article 11 of the Pakistan and Switzerland BIT was merely descriptive and not directly related to the contractual claims. ${ }^{55}$ It concluded that the phrase did not automatically elevate the breach of contract to the violation of international law since such interpretation would lead to incorporating an unlimited number of state contracts. ${ }^{56}$ A similar approach was used by the tribunal in the case of Joy Mining Machinery Limited v. The Arabic Republic of Egypt ${ }^{57}$ and El Paso Energy International Company v. The Argentine Republic ${ }^{58}$.

53 Fedax N.V. v The Republic of Venezuela. Award, ICSID Case No. ARB/96/3, 37 I.L.M. 1391 (1998), 9

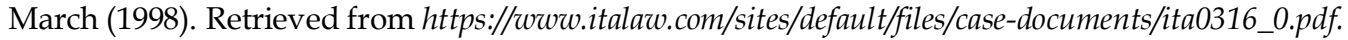

54 Yannaca-Small, K. (2006). Interpretation of the Umbrella Clause in Investment Agreements (OECD Working Papers on International Investment No. 2006/03). https://doi.org/http://dx.doi.org/ 10.1787/415453814578. 9.

55 SGS Société Générale de Surveillance S.A. v. Islamic Republic of Pakistan. Op.cit. 161.

56 Ibid. 166, 168.

57 Joy Mining Machinery Limited v The Arab Republic of Egypt. Award on Jurisdiction, ICSID Case No. ARB/03/11, 6 August (2004). Retrieved from https://www.italaw.com/sites/default/files/case-documents/ ita0441.pdf, 81.

58 The tribunal decided to reject the elevation of the dispute by reason of distinguishing the status of the state as a merchant (as established in the investment agreement) and as a sovereign (as established in the BIT between US and Argentine), El Paso Energy International Company v The Argentine Republic. Decision on Jurisdiction, ICSID Case No. ARB/03/15, 27 April (2006). 70. The same BIT was assessed in Pan American Energy LLC and BP Argentina Exploration Company v. Argentine Republic. The tribunal on the latter case was also in the view that the State was only obliged to give protection as stipulated under the treaty and should not go beyond that, see: Pan American Energy LLC and BP Argentina Exploration Company v The Argentine Republic. Decision on Preliminary Objections, ICSID Case No. ARB/03/13, 27 July (2006). Retrieved from https://www.italaw.com/sites/default/files/casedocuments/ita0616.pdf. 110. 
The broad interpretation was firstly employed in SCG $v$. Philippines. The tribunal criticized the SGS v. Pakistan decision, calling it unconvincing 59 and highly restrictive. 60 It further based its judgment on its Preamble, which mentioned that the treaty was intended to promote mutual investment protection and maintain favorable conditions between the Parties. Accordingly, the tribunal viewed that it had legitimate jurisdiction to resolve uncertainties of interpretation in order to protect the covered investments. ${ }^{61}$ However, the tribunal held that the fact that the umbrella clause had been breached did not necessarily mean that there would be an escalation from breach of contract to violation of international law. ${ }^{62}$ The primary jurisdiction still vested on the contract's forum, and hence, the international proceeding should be suspended until the claimant exhausted such primary jurisdiction. 63

A broader interpretation was made by the tribunal on SGS v. Paraguay. ${ }^{64}$ The company commenced an ICSID arbitration based on an umbrella clause stated in SwitzerlandParaguay BIT due to the failure of the Paraguay Ministry of Finance to perform several invoices. This case was different from its precedents since the tribunal employed a pervasive interpretation of the clause. The tribunal held that the SGS's claims were not co-extensive with the contractual claims as the umbrella clause protected all commitments SGS and Paraguay had entered. Further, the tribunal held that even if the claims might be co-extensive with the contractual claim, the dismissal of the claims based on the argument that the umbrella clause was inadmissible since the contract forum selection clause would be applicable was in effect implied waiver of treaty rights. 65 The BIT is a means of international law and acts as a safeguard for the investor from the domestic law regime. Therefore, it shall maintain its function and shall not be easily waived. The tribunal, then concluded that there was no basis for excluding contracts from the commitments covered by the clause. A similar decision had been made by the tribunal in Sempra Energy International v. Argentina. It recognized that the umbrella clause had brought together the relationship between the contract, the context of the investment, and the relevant BIT.66 Accordingly, it held that the claims arising from an investment contract were considered claims under the treaty since the violation of the investment contract affected the investor's rights as protected by the BIT. 67

The same approach also used in the case of Eureko B.V.v. Poland, which was based on an umbrella clause stated in the Netherlands-Poland BIT, which stipulated "the States should observe any obligations it may have entered about certain foreign investments." The tribunal referred to Article 31, paragraph 1 of the Vienna Convention on the Law of Treaties to interpret the clause and ultimately deciding to go by its ordinary meaning. It found that the phrase "shall observe" is authoritative, and the term "any" is

59 Alexandrov, S. A. op.cit.

60 Alexandrov, S. A., op.cit. 119, 120.

61 SGS Société Générale de Surveillance S.A. v. Republic of the Philippines. Op.cit. 116.

62 Ibid. 128.

63 The claimant was permitted to appeal to the international forum only if the domestic judgment was not satisfactory. Ibid. 136-155, 170-76. One of the three members of the Tribunal, Professor A. Crivellaro, dissented.

64 SGS Société Générale de Surveillance S.A. v. the Republic of Paraguay. Decision on Jurisdiction, ICSID Case No. ARB/07/29, 12 February (2010). Retrieved from https://www.italaw.com/sites/default/files/casedocuments/italaw1526.pdf.

65 Ibid. 178.

66 Sempra Energy International v The Argentine Republic. Decision on Objections to Jurisdiction, ICSID Case No. ARB/02/16, 11 May (2005). 101.

67 Ibid. 100 
capacious. Therefore, the clause can be interpreted broadly, covering any investment obligation entered by the parties. Consequently, the contractual claim, in that case, was subject to the jurisdiction of the tribunal. 68

Over the years, different tribunals have employed different interpretations of the umbrella clause, confirming that multi-interpretation and the failure to give a legal certainty is essentially the fundamental issue of the clause. Even for a very similar case like the SGS cases, which dealt with similar wording of the umbrella clause on related topics, the distinctive approach can be taken by the tribunals. ${ }^{69}$ This situation can be briefly summarized in the following Table 1.

Table 1. The Interpretations of Umbrella Clause

\begin{tabular}{|c|c|c|}
\hline Narrow Interpretation & \multicolumn{2}{|c|}{ Broad Interpretation } \\
\hline Contract Forum Choice & $\begin{array}{c}\text { Exhaust the Contract Forum } \\
\text { before Treaty Forum }\end{array}$ & Treaty Forum Choice \\
\hline $\begin{array}{l}\text { - It is not the purpose of the } \\
\text { umbrella clause to be } \\
\text { interpreted in an } \\
\text { extensive manner. } \\
\text { - The contractual claims } \\
\text { shall not be elevated to an } \\
\text { international claim. }\end{array}$ & $\begin{array}{l}\text { - The umbrella clause is } \\
\text { purposed to give an } \\
\text { assurance to the investors } \\
\text { regarding the performance of } \\
\text { the obligation by the Host } \\
\text { State. } \\
\text { The international proceeding } \\
\text { shall be suspended until the } \\
\text { contract forum selection } \\
\text { clause has exhausted. }\end{array}$ & $\begin{array}{l}\text { - The contractual } \\
\text { commitments are under the } \\
\text { coverage of the umbrella } \\
\text { clause. } \\
\text { The international forum has } \\
\text { jurisdiction to decide } \\
\text { contractual matters based } \\
\text { on the wording of the } \\
\text { umbrella clause. Therefore, } \\
\text { it should not be rendered } \\
\text { inutile. }\end{array}$ \\
\hline $\begin{array}{ll}\text { - } & \text { SGS v. Pakistan } \\
\text { - } & \text { Toto Construzioni v. } \\
& \text { Lebanon } \\
\text { - } & \text { Salini v. Jordan, } \\
\text { - } & \text { El Paso v. Argentina } \\
\text { - } & \text { Siemens v. Argentina } \\
\text { - } & \text { Joy Mining v. Egypt }\end{array}$ & $\begin{array}{ll}\text { - } & \text { SGS v. the Philippines } \\
\text { - } & \text { BIVAC v. Paraguay } \\
\text { - } & \text { Bosh v. Ukraine }\end{array}$ & $\begin{array}{ll}\text { - } & \text { SGS v. Paraguay } \\
\text { - } & \text { Eureko v. Poland } \\
\text { - } & \text { Noble Ventures v. Romania } \\
\text { - } & \text { Burlington v. Ecuador } \\
\text { - } & \text { Duke Energy v. Ecuador } \\
\text { - } & \text { Sempra Energy International } \\
& \text { v. Argentina }\end{array}$ \\
\hline
\end{tabular}

Source: Primary Source, 2018.

\subsection{The Nature of the Investment Contract}

In assessing the breach of an investment contract, which then leads to the violation of an umbrella clause, the tribunal usually tries to analyze the role and the relationship between the investor and the host state. A private party can only escalate the problem of contract performance to international level only if: (1) the State itself that has acted beyond what international law has established; (2) his business can be considered as an investment under the BIT; and (3) he fulfills the definition as an investor under BIT. According to the commentary for the umbrella clause under the OECD draft, the use of the umbrella clause itself is limited only to the investment concerned and cannot be used if the link is incidental. ${ }^{70}$ Such sufficient link can be formed: (1) if the undertaking is covered under the specific undertaking term specified under the treaty; and (2) if it

68 Eureko BV v Republic of Poland. Partial Award, Ad Hoc Arbitration under the Agreement between the Kingdom of the Netherlands and the Republic of Poland on Encouragement and Reciprocal Protection of Investment (2005). 246.

69 De Souza Fleury, R. P. op.cit.

70 OECD (1967). Op.Cit. Notes and Comments to Art. 2, para. 3(a). 
can be proved that the foreigner 'acted in reliance on it ${ }^{71}$ Hence, not all violations of the investment contracts can be brought before the international forum. However, it ultimately depends on the specific nature of the agreement, the parties, the clauses contained in the relevant treaties, and how the tribunal sees the combination of those factors.

The tribunal in Siemens $v$. Argentina held that in order to burden a state with an international responsibility, it must have used its supreme power as a state (something that an ordinary contracting party will not be able to do) and utilizing the public authority. According to the tribunal, the issue turns upon the nature of the state's action itself, whether it is acing in its particular capacity as a government entity or merely as an ordinary contracting party.72

The tribunal in Duke Energy v. Ecuador 73 established a limitation regarding the parties who will be acknowledged in the international forum, concluding a valid investment agreement. The host state cannot be represented by a state-owned entity, and the investor cannot be represented by a local company. The contract should be between the investor and the state themselves. The failure to meet these criteria will limit the parties' protections to those provided under their investment agreement. Thus, any dispute arising from the contract will not invoke the protection of the treaty. ${ }^{74}$ This decision was made on the fact that sometimes the parties to a contract and the parties to a treaty sometimes are not the same. On the side of the host state, the contracting party can be a state entity or a subdivision other than the state itself. On the side of the investor, the contracting party can be its subsidiary instead of the investor itself. For example, the claimant in Noble Ventures $v$. Romania ${ }^{75}$ executed a contract with the Romanian State Ownership Fund, a legal entity separated from the Romanian government. The Tribunal determined that the conduct of the Fund was attributed to the Romanian government since the latter has granted its public authority to the Fund. The Tribunal further held that an act by a governmental agency attributable to its state might constitute a breach of international law as a violation under the umbrella clause. ${ }^{76}$

Other tribunals, including that in the case of Impregilo v. Pakistan, have found the umbrella clause is inapplicable where the state did not execute a contract in its name. ${ }^{77}$ The Impregilo tribunal found that contracts executed by a public entity separate from Pakistan would not come under the protection of the umbrella clause. ${ }^{78}$ In the case of UPS v. Canada, the arbitral tribunal held that it is essential to underline that the governmental entity is exercising public functions that can be attributed to the state. ${ }^{79} \mathrm{It}$

71 Ibid.

72 Siemens A.G. v The Argentine Republic. Award, ICSID Case No. ARB/02/8, 17 January (2007).

73 Duke Energy Electroquil Partners \& Electroquil S.A. v Republic of Ecuador. Award, ICSID Case No. ARB/04/19, 18 August (2008).

74 Burlington Resources Inc. v. Republic of Ecuador. Decision on Jurisdiction, ICSID Case No. ARB/08/5, 2 June (2010).

75 Noble Ventures Inc. v Romania. Award, ICSID Case No. ARB/01/11, 12 October (2005).

76 Ibid. 85.

77 Azurix Corp v The Argentine Republic. Award, ICSID Case No. ARB/01/12, 14 July (2006), 52, 384; EDF (Services) Limited v Romania. Award, ICSID Case No. ARB/05/13, 8 October (2009), 317, 318; Gustav F W Hamester GmbH \& Co KG v Republic of Ghana. Award, ICSID Case No. ARB/07/24, 18 June (2010), 339-50. Impregilo S.p.A. v. Islamic Republic of Pakistan. Decision on Jurisdiction, ICSID Case No. ARB/03/3, 22 April (2005).

78 Impregilo S.p.A. v. Islamic Republic of Pakistan. Op.Cit. 223.

79 United Parcel Service of America Inc. v. Government of Canada. Award on the Merits, ICSID Case No. UNCT/02/1, 24 May (2007). 
further established that a dispute arising between two private actors engaged in commercial rivalries could not be subject to investment arbitration based on treaty rights. Such dispute should involve the state or state entity directly.

Decisions regarding the subsidiaries of investors remain to vary. The tribunal in Continental Casualty v. Argentina ${ }^{80}$ held that the protection of the umbrella clause contained in the investment contract could cover the investor's subsidiary since it was the purpose of the treaty to provide security for the particular investment. Some other tribunals, however, have made contrary decisions by requiring that investment contracts should be executed directly by the foreign investor, not the local subsidiaries. ${ }^{81}$

\section{The Critics toward Umbrella Clause and the Current Investment Protection Standard}

In the early discussion of the umbrella clause, the critics towards the clause's concept were preferably omitted. Many commentators and lawyers, although they understood the effect of the clause clearly, believed that the clause was merely a restatement of pacta sunt servanda principle, which generally accepted by international law. The clause is thought to as a manifestation of the states' good faith in fulfilling their obligations entered with investors ${ }^{82}$ and designed to merely give effect to whatever commitments every State accepts and to protect the aliens in enjoying their rights. ${ }^{83}$

Georg Schwarzenberger and S.D. Metzger were two international lawyers who raised several concerns regarding the clause's ability to change the private contract to an international agreement between countries and made a 'far-reaching departure' from where it first stands. ${ }^{84}$ The concern was also premised on how the clause somehow outsmarted the requirement of local remedies or the contractual forum chosen by the state and the investor, which was probably not the intention of the parties at all during the treaty-making. The umbrella clause was also a counterpart of the customary international law concept of rebus sic stantibus, which might be a hindrance to the use of it. Furthermore, the umbrella clause also made the situation somehow 'tilt the balance too far in favor of the investor ${ }^{85}$

When eventually the issue of the umbrella clause under modern BIT comes into the surface, the situation is somewhat different compared to what had been discussed in

80 Continental Casualty Company v Argentine Republic. Award, ICSID Case No. ARB/03/9, 5 September (2008), 297. Several other tribunals mentioned the same: CMS Gas Transmission Company v The Argentine Republic. Award, ICSID Case No. ARB/01/8, 12 May (2005), 296-303; Sempra Energy International v Argentine Republic. Award, ICSID Case No. ARB/02/16, 28 September 2007 (2007), 308-14; Duke Energy Electroquil Partners \& Electroquil S.A. v Republic of Ecuador. Op. Cit. 314-25.

81 Siemens A.G. v The Argentine Republic. Op. Cit. 204-6; BG Group Plc. v. The Republic of Argentina. UNCITRAL Arbitration Rules, Final Award, 24 December (2007), 206-15; El Paso Energy International Company v. The Argentine Republic. Award, ICSID Case No. ARB/03/15, 31 October (2011), 531-8.

82 Abs, H. J., \& Shawcross, A. (1960). Comment on the Draft Convention by its Authors. Journal of Public Law, 9, 119, 120.

83 The Committee on International Trade and Investment of the Section of International and Comparative Law of the American Bar Association. (1963). The Protection of Private Property Invested Abroad, 9696.

84 Sinclair, A. C., op.cit. citing Schwarzenberger, G. (1960). The Abs-Shawcross Draft Convention on Investment Abroad: A Critical Commentary. Journal of Public Law, 9, 147, 155, and Metzger, S. D. (1960). Multilateral Conventions for the Protection of Private Foreign Investment. Journal of Public Law, 9, 133, 137.

85 Ibid. 
the 1960s as the new culture of investment protection standard has been established. Before the 1990s, it is estimated that only around 25 international investment disputes brought to the international arbitration forum. ${ }^{86}$ By the end of 2016, more than 767 claims against governments have been filed to the international forum, mostly to ICSID, and made supply for case laws. ${ }^{87}$ ICSID soon becomes the main forum for settlement of investment disputes. ICSID was created to balance the interest of investors and host states, 88 as it offers an opportunity to the foreign investors to file a claim against the host State governments. Many developing States apparently decided to join the ICSID forum or other investor-state dispute settlement forum since they want to be seen as an investor-friendly country in the middle of economic competition and responding pressure from the capital-exporting states and the domestic interest groups. 89 The situation has been different compared to what happened during the era of New International Economic Order and Permanent Sovereignty when the capitalexporting States had so much power in their hand to conduct nationalization.

The trend of international investment claims has raised the capital-exporting states' awareness of the potential costs of BITs. Since 2002, the number of new BITs signed has declined in order to minimize exposure to investment arbitration. ${ }^{90}$ Alongside with that, the umbrella clause as one of the doors for States to bring their investment disputes to the international forum has also been omitted on most of the BITs. By 2016, thirty-seven new international investment treaties had been executed, and nearly half of which excluded the umbrella clause. ${ }^{91}$ By 2019, it is estimated that at least 28 of the 29 treaties have omitted the umbrella clause (Figure 1). 92

To proof the breach of the umbrella clause is also rather complicated. The clause generates many issues which should be taken into account by the tribunal, among other things: the distinction between contract-based and treaty-based claims; the need to prove the legality of the authority (puissance publique); the umbrella clause's priority over the forum selection clause in the public contract; the relationship between the parent and subsidiary company respecting the benefit of the clause; as well as the extent to which the clause can cover the state entity. ${ }^{93}$ In July 2017, it was recorded that at least 114 alleged umbrella clause breach cases have been brought before investorState dispute settlement since 1987, whereas only 15 of them are found by the tribunals. ${ }^{94}$ This makes the umbrella clause violation allegation situated in third place after national treatment and full protection and security, proving the ineffectiveness of the clause.

86 Pauwelyn, J. (2005). Rational design or accidental evolution? The emergence of international investment law. In the Foundation of International Investment Law: Bringing Theory into Practice (pp. 11-44). Oxford: Oxford University Press, 30; Calvert, J. (2018). Constructing investor rights? Why some states (fail to) terminate bilateral investment treaties. Review of International Political Economy, 25(1), 75-97.

87 Ibid.

88 Lamm, C. B. (1991). Jurisdiction of the International Centre for Settlement of Investment Disputes. ICSID Review - Foreign Investment Law Journal, 6(2), 462-483..

89 Pauwelyn, Op.Cit. 26, 28.

90 UNCTAD. (2017b). World Investment Report 2017, Investment and the Digital Economy. Geneva. Retrieved from https://unctad.org/en/PublicationsLibrary/wir2017_en.pdf.

91 Ibid.

92 UNCTAD. (2019). World Investment Report, 2019, Special Economic Zones. New York. Retrieved from https://unctad.org/en/PublicationsLibrary/wir2019_en.pdf.

93 De Souza Fleury, R. P. op.cit.

94 UNCTAD. (2017a). Special Update on Investor-State Dispute Settlement: Facts and Figures. International Investment Agreements Issues Note, 8. Retrieved from https://unctad.org/en/ PublicationsLibrary/diaepcb2017d7_en.pdf. 
Figure 1. Number of BITs Signed with and without Umbrella Clause between 1959 and 2016

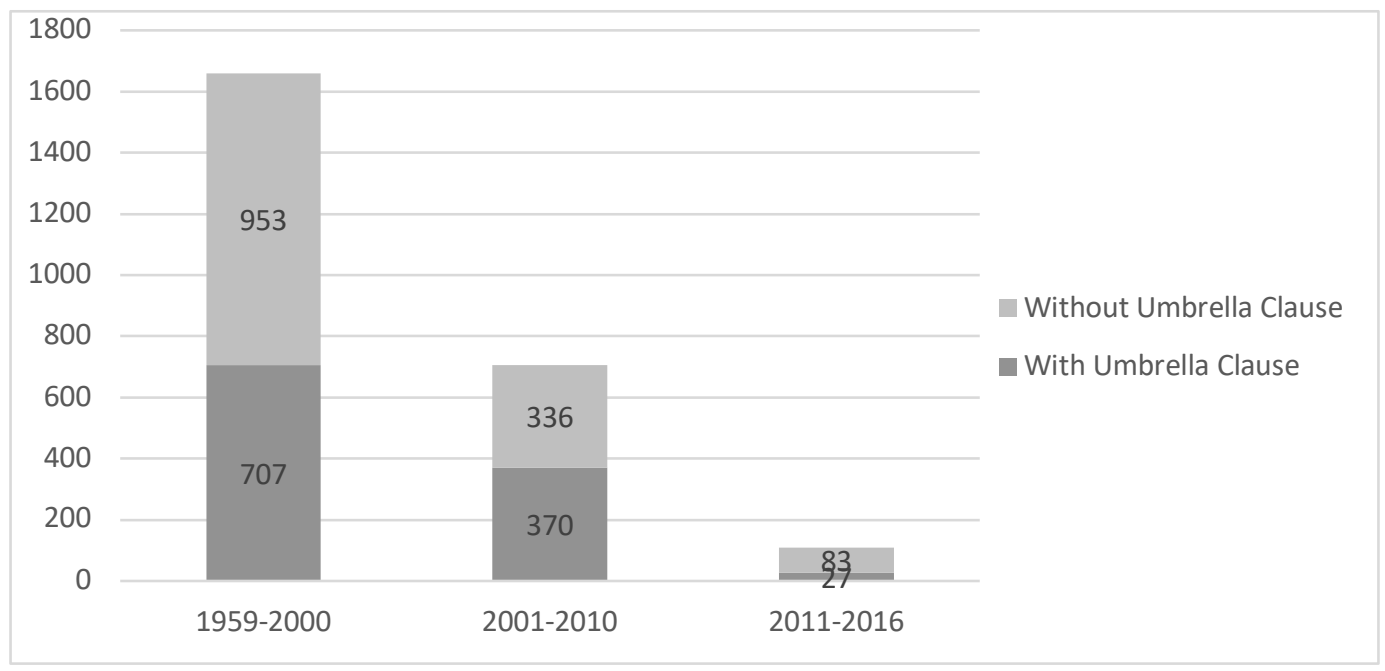

Source: UNCTAD, IIA Mapping Project

Since the issue of the umbrella clause was discussed in SGS v. Pakistan, the clause has been interpreted inconsistently, depending on the specific wording of the clause and the relationship of the parties in case per case basis. Therefore, it seems like there is no legal certainty obtained by the Contracting States by putting the umbrella clause in their BITs. Moreover, the objective of the umbrella clause itself is also somewhat debatable, whether it is purposed to elevate a contractual dispute to become an issue in international law. It seems that the umbrella clause is not intended as a mechanism to disregard a contractual dispute's resolution but rather to show how the treaty should be carried out. Even Lauterpacht made a comment for the parties involved in the AIOC to not engage the clause for every minor contractual dispute. Although he later revised his statement by saying that such choice should be left open in case the Government or the company considered it beneficial to take up a minor problem to the international level (showing the unpredictability of an umbrella clause). ${ }^{95}$ Moreover, the impact of such elevation can result in a massive number of international arbitrations claims, resulting in apparent inefficiencies for the international community.

Currently, 95\% of the available investment treaties in force were concluded before 2010. These old treaties are somewhat inconsistent and make overlapping remarks and fragmentation challenges among treaty relationships. ${ }^{96}$ Most of the international claims are also based on these old treaties. Because of such reasons, states start to revisit their BITs and modernize their commitments. They remain accessible for the new investment. However, the new trend to apply more restrictive measures has started to increase. For example, the 2019 Model BIT of the Netherlands limits the interpretation of the umbrella clause explicitly strictly only to the matters regarding the fair and equitable treatment of investment. Article 9(5) such document said, "When a Contracting Party has entered into a written commitment with investors of the other Contracting Party regarding a specific investment, that Contracting Party shall not, either itself or through an entity exercising governmental authority, breach the said commitment through the exercise of governmental authority in a way that causes loss

95 Lauterpacht (1954a), Op. Cit. 9.

96 UNCTAD. (2019). Op. Cit. xii. 
or damage to the investor or its investment". Further, Article 9(6) mentioned, "For greater certainty, a breach of another provision of this Agreement or any other international agreement does not constitute a breach of this Article. Besides, the fact that a measure breaches domestic law does not, in and of itself, establish a breach of this Article." Similarly, the US also makes a strict limitation regarding the breach of investment agreement that can be brought to arbitration through its 2012 Model BIT, namely only those that related to: (1) natural resources; (2) supply of utility services; or (3) performance of infrastructure projects. Some other states have chosen not to include the clause, ultimately, such as Canada, France, Colombia, Norway, India, and the Czech Republic. ${ }^{97}$ The other States, such as Ecuador, Bolivia, and Venezuela, even have decided to withdraw from the ICSID forum to avoid state-private investor disputes altogether.

\section{Conclusion}

Since its introduction in the 1950s, the concept of the umbrella clause has passed several investment protection standard eras. Regardless of its initial concerns, it becomes a part of the early model of BIT and stays exist during the BITs conclusion wave in the early 90s. It was not until the SGS's cases, the issues regarding the clause finally came into the surface and changed how states perceived the investment protection standards in their BITs. The clause is noteworthy since it brings an extraordinary effect, putting a private contractual issue so close to the breach of public international law and blurring the division between them.

As time passes, the perception of investment has also changed. With easy access to the international forum, the number of investment claims has also increased rapidly during the past decade, and tons of cases have developed the subject more than what has been achieved by the previous years. In the middle of the need for foreign capital, states face the cost of international dispute settlement and decide to reconsider their commitments under investment treaties, including restrict and eliminate the use of the umbrella clause. It finally marks the new era of the international investment protection standard and ends the long debate over the use of 50-years old umbrella clause concept.

\section{References}

Abs, H. J. (1957). The Safety of Capital. San Francisco: San Francisco International Industrial Development Conference in October 1957.

Abs, H. J. (1958). Proposals for Improving the Protection of Private Foreign Investments. Rotterdam: Investments (Institut International d'Etudes Bancaires).

Abs, H. J., \& Shawcross, A. (1960). Comment on the Draft Convention by its Authors. Journal of Public Law, 9, 119.

Abs, H., \& Shawcross, A. (1960). The Proposed Convention to Protect Private Foreign Investment. Journal of Public Law, 9, 115.

Agrawal, K. (2016). Bilateral investment treaties: a developing history. Jindal Global Law Review, 7, 175-199. https://doi.org/https://doi.org/10.1007/s41020-016-0031-x

Alexandrov, S. A. (2004). Breaches of Contract and Breaches of Treaty - The Jurisdiction of Treaty-based Arbitration Tribunals to Decide Breach of Contract

97 UNCTAD. (n.d.). Model Agreements. Retrieved January 30, 2020, from https://investmentpolicy. unctad.org /international-investment-agreements/model-agreements. 
Claims in SGS v. Pakistan and SGS v. Philippines. Journal of World Investment and Trade, 4(5), 125.

Anglo-Iranian Oil Co. Case (the United Kingdom v. Iran). Jurisdiction, ICJ Report Judgment of July 22nd (1952).

Asante, S. K. B. (1988). International Law and Foreign Investment: A Reappraisal. The International and Comparative Law Quarterly, 37(3), 588-628. Retrieved from https://www.jstor.org/stable/760279

Azurix Corp v The Argentine Republic. Award, ICSID Case No. ARB/01/12, 14 July (2006).

BG Group Plc. v. The Republic of Argentina. Final Award, UNCITRAL Arbitration Rules, 24 December (2007).

Burlington Resources Inc. v. Republic of Ecuador. Decision on Jurisdiction, ICSID Case No. ARB/08/5, 2 June (2010).

Calvert, J. (2018). Constructing investor rights? Why some states (fail to) terminate bilateral investment treaties. Review of International Political Economy, 25(1), 75-97. https://doi.org/https://doi.org/10.1080/09692290.2017.1406391

CMS Gas Transmission Company v The Argentine Republic. Award, ICSID Case No. ARB/01/8, 12 May (2005).

Continental Casualty Company v Argentine Republic. Award, ICSID Case No. ARB/03/9, 5 September (2008).

De Souza Fleury, R. P. (2017). Closing the umbrella: A Dark Future for Umbrella Clause? Retrieved January 31, 2020, from http://arbitrationblog. kluwerarbitration.com/2017/10/13/closing-umbrella-dark-future-umbrella-clauses/

Denza, E., \& Brooks, S. (1987). Investment Protection Treaties: United Kingdom Experience. The International and Comparative Law Quarterly, 36(4), 908-923. Retrieved from https://www.jstor.org/stable/760362

Dolzer, R., \& Schreuer, C. (2012). Principles of International Investment Law (Second). Oxford University Press.

Dolzer, R., Stevens, M., \& ICSID. (1995). Bilateral Investment Treaties. The Hague: Martinus Nijhoff Publishers.

Duke Energy Electroquil Partners \& Electroquil S.A. v Republic of Ecuador. Award, ICSID Case No. ARB/ 04/19, 18 August (2008).

EDF (Services) Limited v Romania. Award, ICSID Case No. ARB/05/13, 8 October (2009).

El Paso Energy International Company v. The Argentine Republic. Award, ICSID Case No. ARB/03/15, 31 October (2011).

El Paso Energy International Company $v$ The Argentine Republic. Decision on Jurisdiction, ICSID Case No. ARB/03/15, 27 April (2006).

Eureko BV v Republic of Poland. Partial Award, Ad Hoc Arbitration under the Agreement between the Kingdom of the Netherlands and the Republic of Poland on Encouragement and Reciprocal Protection of Investment (2005).

Fedax N.V. v The Republic of Venezuela. Award, ICSID Case No. ARB/96/3, 37 I.L.M. 1391 (1998), 9 March (1998). Retrieved from https://www.italaw.com/sites/ default/files/case-documents/ita0316_0.pdf

Fernández Jilberto, A. E., \& Mommen, A. (Eds.). (1996). Liberalization in the developing world : institutional and economic changes in Latin America, Africa, and Asia. London; New York: Routledge.

Gill, J., Gearing, M., \& Bert, G. (2004). Contractual Claims and Bilateral Investment Treaties, A Comparative Review of the SGS Cases. Journal of International Arbitration, 21(5), 397-412. 
Gustav F W Hamester GmbH \& Co KG v Republic of Ghana. Award, ICSID Case No. ARB/ 07/24, 18 June (2010).

Guzman, A. T. (1998). Why LDCs Sign Treaties That Hurt Them: Explaining the Popularity of Bilateral Investment Treaties. Virginia Journal of International Law, 38, 639-688.

Hackworth, G. H. (1942). Digest of International Law (Vol 3). Washington: United States Government Printing Office.

Impregilo S.p.A. v. Islamic Republic of Pakistan. Decision on Jurisdiction, ICSID Case No. ARB/03/3, 22 April (2005).

Joy Mining Machinery Limited v The Arab Republic of Egypt. Award on Jurisdiction, ICSID Case No. ARB/03/11, 6 August (2004). Retrieved from https://www.italaw.com/sites/default/files/case-documents/ita0441.pdf

Lamm, C. B. (1991). Jurisdiction of the International Centre for Settlement of Investment Disputes. ICSID Review - Foreign Investment Law Journal, 6(2), 462-483. https://doi.org/https://doi.org/10.1093/icsidreview/6.2.462

Lauterpacht, E. (1953). Anglo-Iranian Oil Company Ltd Persian Settlement - Note dated 7 December 1953.

Lauterpacht, E. (1954a). Anglo-Iranian Oil Company Ltd Persian Settlement - Note dated 12 March 1954.

Lauterpacht, E. (1954b). Anglo Iranian Oil Company Ltd Persian Settlement - Opinion dated 20 January 1954.

Lipson, C. (1985). Standing Guard, Protecting Foreign Capital in the Nineteenth and Twentieth Centuries. London: University of California Press.

Metzger, S. D. (1960). Multilateral Conventions for the Protection of Private Foreign Investment. Journal of Public Law, 9, 133.

Moore, J. B. (1906). A Digest of International Law (Vol 4). Washington: Government Printing Office.

Ng'ambi, S. P. (2015). Permanent Sovereignty Over Natural Resources and the Sanctity of Contracts, From the Angle of Lucrum Cessans. Loyola University Chicago International Law Review, 12(2), 153-172. Retrieved from https://lawecommons.luc.edu/cgi/viewcontent.cgi? article $=1176 \&$ context=lucilr.

Noble Ventures Inc. v Romania. Award, ICSID Case No. ARB/01/11, 12 October (2005).

OECD. Draft Convention on the Protection of Foreign Property 12 October (1967). Retrieved from https://www.oecd.org/daf/inv/internationalinvestmentagreements/ 39286571.pdf.

OECD. (2008). International Investment Law: Understanding Concepts and Tracking Innovations: A Companion Volume to International Investment Perspectives. Paris: OECD Publishing. https://doi.org/https://doi.org/10.1787/9789264042032-en.

Pan American Energy LLC and BP Argentina Exploration Company v The Argentine Republic. Decision on Preliminary Objections, ICSID Case No. ARB/03/13, 27 July (2006). Retrieved from https://www.italaw.com/sites/default/files/casedocuments/ita0616.pdf.

Pauwelyn, J. (2005). Rational design or accidental evolution? The emergence of international investment law. In the Foundation of International Investment Law: Bringing Theory into Practice (pp. 11-44). Oxford: Oxford University Press.

Root, E. (1910). The Basis of Protection to Citizens Residing Abroad. In American Society of International Law at Its Annual Meeting (1907-1917) (pp. 16-27). Cambridge University Press. Retrieved: https://www.jstor.org/stable/25656384. 
Schwarzenberger, G. (1960). The Abs-Shawcross Draft Convention on Investment Abroad: A Critical Commentary. Journal of Public Law, 9, 147.

Sempra Energy International v Argentine Republic. Award, ICSID Case No. ARB/ 02/16, 28 September 2007 (2007).

Sempra Energy International v The Argentine Republic. Decision on Objections to Jurisdiction, ICSID Case No. ARB/02/16, 11 May (2005).

SGS Société Générale de Surveillance S.A. v. Islamic Republic of Pakistan. ICSID Case No. ARB/01/13 Decision of the Tribunal on Objections to Jurisdiction (2003). Retrieved from $h t t p s: / / w w w . i t a l a w . c o m / c a s e s / 1009$.

SGS Société Générale de Surveillance S.A. v. Republic of the Paraguay. Decision on Jurisdiction, ICSID Case No. ARB/07/29, 12 February (2010). Retrieved from https://www.italaw.com/sites/default/files/case-documents/italaw1526.pdf.

SGS Société Générale de Surveillance S.A. v. Republic of the Philippines. ICSID Case No. ARB/02/6 Decision of the Tribunal on Objections to Jurisdiction. Retrieved from $h t t p s: / / w w w . i t a l a w . c o m / s i t e s / d e f a u l t / f i l e s / c a s e-d o c u m e n t s / i t a 0782 . p d f$.

Shan, W. (2007). Is Calvo Dead? The American Journal of Comparative Law, 55(1), 123-163.

Shea, D. R. (1955). The Calvo Clause: A Problem of Inter-American International Law and Diplomacy. University of Minnesota Press. Retrieved from https://www.jstor.org/stable/10.5749/j.ctttt1ms.

Siemens A.G. v The Argentine Republic. Award, ICSID Case No. ARB/02/8, 17 January (2007).

Sinclair, A. C. (2004). The Origins of the Umbrella Clause in the International Law of Investment Protection. Arbitration International, 20(4), 411-434.

Sornarajah, M. (2010). The International Law on Foreign Investment (Third). New York: Cambridge University Press.

Subedi, S. P. (2008). International Investment Law Reconciling Policy Principle. Oxford and Portland, Oregon: Hart Publishing.

Sutton, S. D. (2005). Emilio Augustin Maffezini v. Kingdom of Spain and the ICSID Secretary-General's Screening Power. Arbitration International, 21(1), 113-126. Retrieved from $h$ ttps://doi.org/10.1093/arbitration/21.1.113.

The Committee on International Trade and Investment of the Section of International and Comparative Law of the American Bar Association. (1963). The Protection of Private Property Invested Abroad.

UNCTAD. (n.d.). Model Agreements. Retrieved January 30, 2020, from https://investmentpolicy.unctad.org/international-investment-agreements/modelagreements.

UNCTAD. (2017a). Special Update on Investor-State Dispute Settlement: Facts and Figures. International Investment Agreements Issues Note, 8. Retrieved from https://unctad.org/en/PublicationsLibrary/diaepcb2017d7_en.pdf.

UNCTAD. (2017b). World Investment Report 2017, Investment and the Digital Economy. Geneva. Retrieved from https://unctad.org/en/PublicationsLibrary/ wir2017_en.pdf.

UNCTAD. (2019). World Investment Report, 2019, Special Economic Zones. New York. Retrieved from https://unctad.org/en/PublicationsLibrary/wir2019_en.pdf.

United Nations Conference on Trade and Development. (1998). Bilateral Investment Treaties in the Mid-1990s. New York: United Nations Publication.

United Nations General Assembly Resolution 14 December. (1962). Permanent Sovereignty over Natural Resources (No. 1803 (XVII)). Retrieved from https://www.un.org/ga/search/view_doc.asp?symbol=A/RES/1803(XVII). 
United Parcel Service of America Inc. v. Government of Canada. Award on the Merits, ICSID Case No. UNCT/02/1, 24 May (2007).

Williamson, J. (2004). The Strange History of the Washington Consensus. Journal of Post Keynesian Economics, 27(2), 195-206. Retrieved from https://www.jstor.org/ stable/4538920.

Yannaca-Small, K. (2006). Interpretation of the Umbrella Clause in Investment Agreements (OECD Working Papers on International Investment No. 2006/03). https://doi.org/http://dx.doi.org/10.1787/415453814578

\section{Conflict of Interest Statement:}

The author(s) declares that the research was conducted in the absence of any commercial or financial relationships that could 